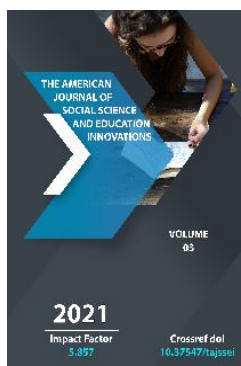

\title{
Gender Equality - Increasing The Role Of Women In Social And Political Life Problems
}

\author{
Gulnoza Odilovna Ochilova \\ Doctor Of Philosophy In Psychology (PhD), Associate Professor Of Department Of "Innovative \\ Education", Tashkent State University Of Economics, Uzbekistan
}

Journal Website:

http://theamericanjour

nals.com/index.php/taj

ssei

Copyright: Original content from this work may be used under the terms of the creative commons attributes 4.0 licence.

\section{ABSTRACT}

This article examines the dependence of family business on entrepreneurial motivation in youth, the study of women's gender equality in entrepreneurship and business, gender equality - the role of women in social and political life, the main features of gender management, socio-psychological development of entrepreneurial skills The problems and main results of the research aimed at studying the properties.

\section{KEYWORDS}

Gender management, interpersonal relationships in the family, family business, gender equality, business ability, motive, gender relations, division of roles in business, motivation to succeed, attitudes.

\section{INTRODUCTION}

As a result of reforms in the formation of an efficient economy in our country, in particular, the improvement of market mechanisms, all forms of private property have developed, family business and entrepreneurship have received more and more attention, state support and a wide path. 
The processes of liberalization and modernization of the real sector of the economy, technical and technological reequipment have served to improve business activity, which in turn has led to a radical change in the attitude of citizens to private property and labor. In recent years, a number of measures have been taken to develop family businesses, provide employment, and provide large-scale financial support for youth and women's initiatives.

One of the key issues of today's reforms is the implementation of profound structural changes in the economy in a short time, ensuring the growth of incomes, strengthening effective foreign trade and investment processes, sustainable development of family business, private entrepreneurship, farming and strengthening entrepreneurship, cultivating the qualities of the individual that allow this activity, the formation of a new economic thinking in the minds of citizens is one of the most pressing issues today.

At the same time, today's scientific and technological progress, as well as the innovative changes taking place in the world market, do not allow us to be limited by the achievements.

In particular, over the years, the largest investments in the real sector of the economy, diversification of the economy, technical and technological re-equipment, restructuring and modernization of bankrupt enterprises, restructuring of various sectors and industries of the economy. going remains one of the urgent tasks.

Effective use of labor potential plays an important role in the high level of development of any country. Therefore, to ensure further development, the amount of investment in human capital in society requires a constant increase.

Today, under the leadership of President Sh. Mirziyoyev, the tasks of creating permanent jobs for women, as well as taking urgent measures to develop family business, homebased work, handicrafts, and horticulture have been identified and are being implemented.

In Uzbekistan, a lot of attention is paid to women's issues. Their rights, freedoms and legitimate interests are enshrined in our Constitution and laws.

Today, we all see and feel in practice that the women of Uzbekistan are gaining their place in all spheres. Last year, for the first time in the history of our country, the number of women in the national parliament rose to today's level. Of the 150 deputies elected to the Legislative Chamber of the Oliy Majlis, 48 or 32 percent were women. In the Senate, the figure was about 25 percent.

Therefore, when we say gender equality, we should not create misconceptions in the minds of our people, because gender equality is a very beautiful concept. This also means that men and women should be given equal opportunities in everything. That is, the creation of equal opportunities for men and women in education, career choice, promotion - gender equality.

Thirty-one percent of local councilors are also passionate, active women. As a result, the Uzbek parliament has risen to 37th place among 190 national parliaments in the world in terms of the number of women deputies. However, 5 years ago we were in 128th place. Some may say that it is good that a woman is a leader. 
The answer to this question is clear: the owners of the sensitive world approach social issues with a more heartfelt approach, making decisions through the heart. And social issues are the pain of the people, the problem of the people, the problems they are going through day and night.

Another reason a woman feels this more, more deeply, is that she is a housewife, a caregiver of children, a doctor who cares about their health. It is precisely because of these qualities that our women, who are active in political life, strive for the laws to be more vital, in which they strive to express specific issues, solutions to problems.

It is known that in modern economic conditions, individual labor activity is one of the most effective ways to solve the problem of employment. Therefore, it is not only a means of improving family conditions, but also manifests itself as a mechanism for economic development. Therefore, it is expedient to assess the advantages and disadvantages of "family business" and to study the scale of economic, sociopsychological factors that affect it.

Our observations show that the formation of a "family business" will solve the problem of employment of more women.

The existing common values that define the family responsibilities of women, in modern conditions, not only serve their recognition among the whole community, but also lead to an increase in the scale of patriarchal influence.

It is well known that most women have only traditional notions about their professional lives and their place in society. A woman with a child is always faced with the problem of choosing one of the opportunities for the well-being of her family or for a career.

The main difference between "family business" and other types of entrepreneurship is that family and work are inextricably linked. At the same time, there is an opportunity for a convenient work schedule and division of labor for all family members gathered in the process of carrying out activities. Family conditions, under the direct influence of parents, made it possible to more effectively organize the economic socialization of young people, to properly educate them in economic thinking, to form in them an active attitude to socio-economic life, to identify and implement research problems.

Therefore, the government needs to identify a number of problems that contribute to the development of family business in the country, to study the specifics of the individual entrepreneur, to study the socio-psychological aspects of the factors that motivate entrepreneurship and related to the family environment. It is important for the successful implementation of the task set by the head of the industry.

Psychological observations show that in recent years there has been a dramatic change in the worldview of women working in entrepreneurship and business. In our country, the increase in the share of women in the management of production and industry, the manifestation of their oriental qualities, in turn, expands the opportunities to identify ethno-psychological aspects of gender equality.

Gender - from a psychological point of view, with its help, the essence of the concept of "man and woman" is highlighted. Since the concept of 'gender' is a biological category, the term is used in social psychology to justify 
the biological interdependence of differences in male and female traits.

The concept of gender does not only represent the interests of women. The bold move of both sexes towards their dreams and goals only implies the need to provide equal opportunities to improve the quality of life. One of the demands of a developed society is to ensure equality between men and women. This, in turn, will greatly contribute to political and economic growth in each country, experts said.

Today, the importance of gender equality in social relations, which is important in the development of society, is becoming more and more obvious. Today, as a result of special attention paid to increasing the activity of women in the family, society, especially in social life, it is said that great changes are taking place in both social relations and legislation.

He outlined the priorities of political, social and economic modernization of Uzbekistan. Among the directions, the issue of gender was of particular importance. In his speech, the head of our state said, "Gender equality policy has become a priority for us. The role of women in public administration is growing.

The number of women deputies in our new parliament has doubled, "she said, referring to the work being done in the country on women's policy. Indeed, in our country, providing all the conditions for women to reach their full potential has risen to the level of public policy.

Indeed, with $49 \%$ of the country's population being women and about $64 \%$ of them being women under the age of 30 , it is necessary to pursue a separate state policy in this direction.
A number of practical measures have been taken in our country to ensure gender equality and improve the living conditions of women, comprehensive support and development of the family, the implementation of international norms on the elimination of all forms of discrimination against women in national legislation, as well as women's legal culture.

If we look at how attention is paid to gender issues in the international arena, it is clear that there are still a number of problems in ensuring gender equality in the world. For example, according to the International Labor Organization, for every 10 working men, there are 6 working women.

At the 74th session of the UN General Assembly, which began its work on September 24, 2019, the women's wing of the organization also highlighted the issues of gender equality, ensuring equal rights and freedoms for women in achieving sustainable development. It was also criticized that only 17 of the 192 speakers at the General Assembly session were women.

The Law on Guarantees of Equal Rights and Opportunities for Women and Men emphasizes the prohibition of direct and indirect discrimination against women on the basis of sex.

This law was developed in accordance with the Resolution of the President of the Republic of Uzbekistan dated March 7, 2019 "On measures to further strengthen the guarantees of women's labor rights and support entrepreneurship." The purpose of this law is to protect women from all forms of oppression and violence in marriage, in the workplace, in educational institutions and elsewhere. 
Regulation of relations in this area, as well as ensuring legal and social protection of victims of repression and violence is also one of the important objectives of the law.

The initial housing allowance for 1,454 women living in difficult living conditions was paid from the Public Fund for Women and Family Support, and 25 billion soums were allocated for these purposes. $194 \mathrm{mln}$. soums were directed. In addition, more than 13,000 women in this category have been employed.

More than 250,000 women have been employed under the employment program. A reserve of more than 6,000 women, with political and legal knowledge, innovative ideas and organizational skills, has been formed.

In short, the strengthening of the role of women in society in achieving gender equality in our country, thereby strengthening the family, raising a young generation with a high intellectual level, is a guarantee of social stability.

Indeed, women, who are actively involved in home-based, family business, farming in Uzbekistan, also have unique entrepreneurial qualities, which allows them to study the role of women in the introduction of effective methods of entrepreneurship for the development of this sector. The education of the qualities of the giver, the formation of new economic thinking in the minds of people, especially in the minds of the younger generation, the development of managerial qualities are of great practical importance.

In recent years, work has been done to ensure gender equality and increase the role of women in social and political life in several areas:
Improving the legislation on women's rights; improving the institutional framework for the protection of women;

Raising public awareness of gender equality and women's rights; training of officials responsible for ensuring compliance with law enforcement practices in accordance with relevant legal norms.

Uzbekistan has adopted a number of laws, including presidential decrees and resolutions on women's rights, in particular, gender equality and protection of women from violence and oppression, strengthening the status of women's entrepreneurship.

Positive shifts in education should be highlighted in terms of the introduction of gender equality. That is, since 2017, the activities of part-time departments in various specialties have been restored in most universities.

This form of education allows young women to pursue higher education without interfering with child care and other family responsibilities. In the field of education alone, we have had differences in the future of girls 'and boys' education and career choices, and we still have such a worldview.

True, all children are taught in school. But then when it comes to choosing a profession, to study in a higher education institution, more attention and priority is given to the education of the boy, to the creation of all conditions for him. Because in some people, only the boy needs to be educated, to be taught, because the view that he is our breadwinner prevails.

If we analyze the role of young men and women in Uzbekistan in the system of gender relations and the distribution of roles, it should be noted that gender roles depend 
entirely on the cultural environment, and this role varies according to their level of education. But while opinion polls acknowledge that Uzbek women are completely equal to men in gender relations, in the minds of many, women are still seen as part of their traditional roles.

There are both positive and negative aspects to this situation. For example, experimental observations by psychologists have shown that the nature of gender relations, the adequacy of masculine or feminine roles, depends primarily on the family environment, how men and women, parents play their roles and their role in child rearing.

Also, the content, effectiveness and level of upbringing of young people in a family environment and the formation of institutions for entrepreneurial activity are directly related to the social and family environment, interpersonal relationships that affect them. Because in any situation, the family social environment, first of all, forms human, economic, spiritual relations in the individual.

The entrepreneurial tendencies and entrepreneurial motivations of young people in families engaged in family business and entrepreneurial activity were based on personal attitudes, gender attitudes and social attitudes of parents.

If we analyze the economic activity of the world's population today on the basis of gender approaches, it should be noted that the employment of women is growing. In particular, we can see that the share of women in the economic activity of the population of Uzbekistan is much higher than in other countries.

Therefore, in line with the words of President Sh. Mirziyoyev: "Critical analysis, strict discipline and personal responsibility - should be a daily rule of every leader," we must address the following important tasks.

First of all, it should be to further strengthen the foundations of the family, which are sacred to us, to create an atmosphere of peace, harmony and mutual respect in the home, to fill the spiritual and enlightenment work with concrete content.

Second, we need to pay serious attention to the bitter and unpleasant issues that are not specific to our people, such as crime among women, the increase in family divorces, the exposure of young people to various religious extremist movements and terrorist organizations.

Thirdly, we need to accelerate the development of family business, home-based work, handicrafts, and horticulture in order to create permanent jobs for women.

Based on the above, we consider it appropriate to take the following measures to involve women in small business and private entrepreneurship in the use of their labor:

Introduction of modern social protection of women;

Organization of various courses (preferential) and expansion of training centers in order to increase women's literacy in the field of entrepreneurship, to improve their skills;

Preferential approaches in supporting women in employment;

Carrying out separate research and study of the problems in the system of employment of unemployed women in labor exchanges and on this basis to improve employment services; 
\# Strengthening the sense of ownership of individual entrepreneurship in rural areas;

* Creation of new jobs based on the development of home-based work and the development of modern industries.

So, the main reason that motivates women to do business is financial incentives, selfrealization and interest in the profession come second. Somehow, the entrepreneurial activism of the majority of women testifies to coercion.

Therefore, in the "Year of Youth Support and Public Health", commercial banks are studying the need for banking services and loans for each household to start a business in order to become an entrepreneur.

This means that if the intelligent, middle-class, business-minded and enterprising women of our country make a worthy contribution to the development of every sphere, the economy of our country will inevitably develop further and achieve high results.

\section{REFERENCES}

1. Ochilova, G. O. EMPIRICAL RESEARCH RESULTS OF FAMILY BUSINESS INFLUENCE ON CHILDREN'S MOTIVATION FOR ENTREPRENEURSHIP.

2. Ochilova G. Ёшларни тадбиркорликка психологик жихатдан тайёрлаш //Архив научных исследований. 2021.

3. Ochilova, Gulnoza. "Оилавий тадбиркорлик гендер тадқиқотлар объекти сифатида." Архив научных исследований (2021).

4. Очилова Г. Гендерные аспекты семейного бизнеса в Узбекистане
//Архив научных исследований. 2019.

5. Очилова, Г. О., \& Мусаханова, Г. М. (2017). Педагогика как наука на пути новых исследовательских задач, переосмыслений и перспектив. Молодой ученый, (7), 458-460.

6. Hayitov O. E., Ochilova G. O. Business Psychology. - 2010.

7. Adilovna, O. G., \& Khayitovich, B. E. GENDER FEATURES OF THE IMPACT OF FAMILY BUSINESS ON YOUTH ENTREPRENEURSHIP MOTIVATION. 